\title{
Poly(benzimidazole)-functionalized graphene supported Pt electrocatalyst and its application in high temperature PEM fuel cells
}

\author{
Permyakova, Anastasia Aleksandrovna; Jensen, Jens Oluf; Li, Qingfeng; Bjerrum, Niels
}

Published in:

Abstract book - Pacific Rim Meeting on Electrochemical and Solid-State Science: 222nd Meeting of ECS - The Electrochemical Society and 2012 Fall Meeting of The Electrochemical Society of Japan

Publication date:

2012

Document Version

Publisher's PDF, also known as Version of record

Link back to DTU Orbit

Citation (APA):

Permyakova, A. A., Jensen, J. O., Li, Q., \& Bjerrum, N. (2012). Poly(benzimidazole)-functionalized graphene supported Pt electrocatalyst and its application in high temperature PEM fuel cells. In Abstract book - Pacific Rim Meeting on Electrochemical and Solid-State Science: 222nd Meeting of ECS - The Electrochemical Society and 2012 Fall Meeting of The Electrochemical Society of Japan [Abstract \#1424]

\section{General rights}

Copyright and moral rights for the publications made accessible in the public portal are retained by the authors and/or other copyright owners and it is a condition of accessing publications that users recognise and abide by the legal requirements associated with these rights.

- Users may download and print one copy of any publication from the public portal for the purpose of private study or research.

- You may not further distribute the material or use it for any profit-making activity or commercial gain

- You may freely distribute the URL identifying the publication in the public portal 


\section{Poly(benzimidazole)-functionalized graphene supported Pt electrocatalyst and its application in high temperature PEM fuel cells}

\author{
Anastasia A. Permyakova, Jens Oluf Jensen, \\ Qingfeng Li, and Niels J. Bjerrum
}

Department of Energy Conversion and Storage Technical University of Denmark, Kemitorvet 207, 2800 Kgs. Lyngby, Denmark

It is widely known that the performance and durability of PEM fuel cells are strongly dependent on the catalyst support structure and properties [1-2]. In order to enhance the catalytic activity, increase the utilization of Pt-based catalysts and thus lower the costs, highly stable supports with large surface areas for the efficient dispersion of Pt nanoparticles are required.

Due to its high surface area and excellent electronic conductivity, graphene has attracted great attention as mechanically and thermally stable and durable as a 2-D support. Graphene has a greater surface area than carbon nanotubes (CNTs) which are among the most efficient carbon supports [2]. Similar to CNTs, graphene requires an investigation into the chemical functionalization methods needed to obtain high dispersion and homogeneous loading of $\mathrm{Pt}$ nanoparticles on the surface. Recently, it was found that poly(benzimidazole) (PBI) can act as $\mathrm{Pt}$ nanoparticle adsorbent for PBI-wrapped CNTs [3]. PBI wrapping leads to more efficient Pt loading, possibly due to the formation of the so called triple-phase boundary nanostructures formed between CNTs, aromatic nitrogen incorporated in the PBI structure, and Pt nanoparticles.

In this study, we have systematically investigated the effects of the PBI-functionalized graphene as a support for Pt-based electrocatalyst (Pt/Graphene-PBI). Graphene/PBI composites were prepared by adding graphene to a PBI/DMAc solution with subsequent sonication, filtration, washing out undoped PBI with DMAc and drying under vacuum [3]. Pt supported on graphene/PBI composites (Pt/graphene-PBI) were prepared from platinum nanoclusters in organic media as described in the literature [4]. The transmission electron microscope (TEM) image [Figure 1] shows the uniform $\mathrm{Pt}$ particles distribution on the $\mathrm{PBI}$ functionalized graphene sheet, with narrow (lower than $2 \mathrm{~nm}$ ) particle size.
The clear evidence of PBI functionalized graphene was detected by FTIR spectroscopy [Figure 2].

The efficiency potential of Pt/Graphene-PBI as a catalyst for oxygen reduction reaction (ORR) and its stability/durability will be presented.

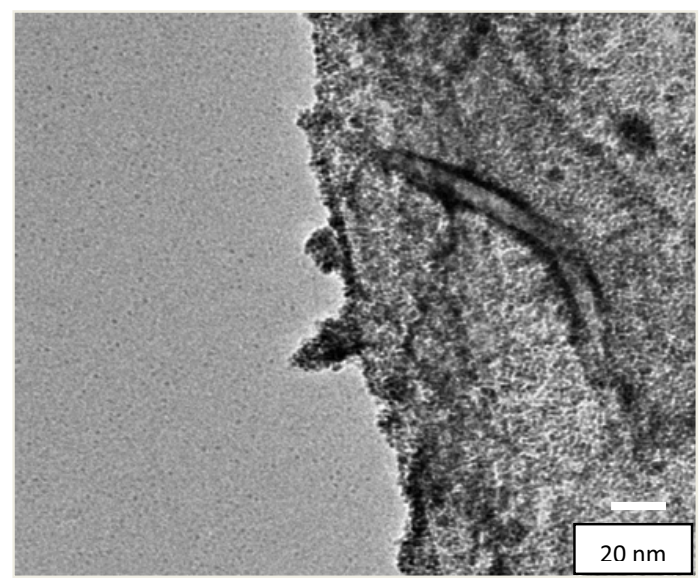

Figure 1. TEM image of $40 \% \mathrm{Pt} / \mathrm{graphene}-\mathrm{PBI}$ catalyst.

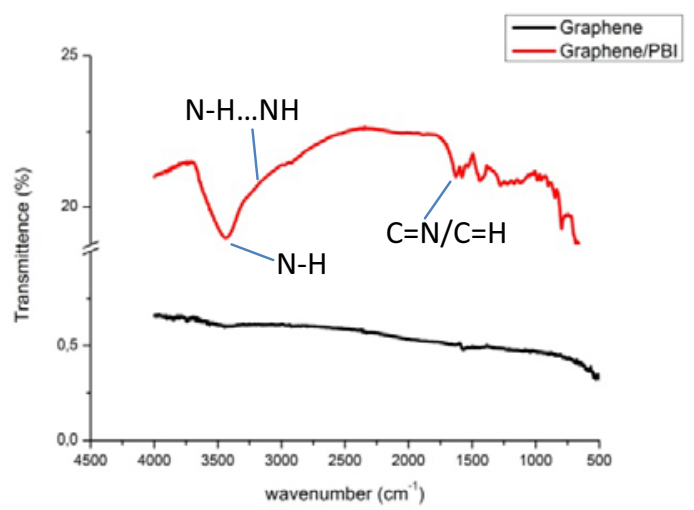

Figure 2. FTIR spectra of un-functionilized graphene (black line) and PBI-functionalized graphene (red line).

[1] C. Subban, Q. Zhou, B. Leonard, C. Ranjan, H. M. Edvenson, F. J. Disalvo, S. Munie and J. Hunting, Phil. Trans. R. Soc. A (2010) 368, 32433253

[2] B. Seger, P. V. Kamat, J. Phys. Chem. Lett. (2009) 113, 7990-5

[3] M. Okamoto, T. Fujigaya and N. Nakashima. Small (2009) 5, 735

[4] Y. Wang, J. Ren, K. Deng, L. Gui, and Y. Tang, Chem. Mater. (2000) 12, 1622-1627 